\title{
COMPARATIVE EFFICIENCY OF DIFFERENT SHAPES AND MATERIALS OF TRAPS FOR SUBTERRANEAN HARVESTER TERMITES, ANACANTHOTERMES OCHRACEUS (BURM.) AT ISMAILIA GOVERNORATE, EGYPT.
}

\author{
Abbas K. M. and Maselleum I. T. \\ Plant Protection Research Institute, Dokki, Giz, Egypt \\ ABSTRACT:
}

This study was carried out at El-kasasien district, Ismailia governorate from April 2013 until July 2013 to evaluate the efficiency of three shapes of termite traps and also from September 2013 until November 2013 to evaluate the efficiency of five trapping materials for the subterranean harvester termites Anacanthotermes ochraceus (Burm.). Results showed that food consumption varied with trap shape though food consumption was almost similar throughout four months. The most efficiency was the plastic trap followed by the corrugated card board trap, while the least was the P.V.C trap. Significant differences were found, where the mean values of food consumption were $18.29,14.08$, and $6.46 \mathrm{~g} /$ trap, with mean numbers of captured termites of $11.18,6.83$, and 4.32 individuals/ trap, respectively.

The highest food consumption, soil translocation and number of captured termites occurred in corrugated cardboard material used for trapping followed by cellulose, toilet papers, and wooden particles, while the lowest consumption wooden stakes. Significant differences were found between cardboard and cellulose and between toilet paper, wooden particles and wooden stakes.

Key words: Subterranean termites, Anacanthotermes ochraceus, Foraging activity, Traps, Baiting materials

\section{INTRODUCTION:}

Anacanthotermes ochraceus is the most common termite in Lower Egypt.

Its range extends from Cairo to the Mediterranean coast. However, it was collected from 13 governorates. This subterranean termite A. ochraceus is the most economic species causing considerable damage to houses Kassab et al. 1960 ; Harris, 1961; Kaschef and El-Sherif, 1971; Said, 1979 and Ali, 1980. The range of food materials eaten by termites has been reviewed by Brian, 1978. The basic food of termites is plant material: living, recently dead, dead but in various stages of decomposition and soil rich in organic matter (so-called humus). Only under unusual circumstances other substances, such as leather or plastics are attacked.The trophic levels of termites are those of primary consumers (i.e. herbivores and decomposers).Termites are not predators, although they are cannibalistic within the colony or, occasionally, attack vertebrate corpses consuming skins, feathers and dried-out tissues. Harris, 1970 stated that the harvester termites of the genus Anacanthotermes are associated with semi desert conditions, which support some vegetation, permit the grazing of domestic animals and irrigation allows the cultivation of crops. Their food consists largely

Fayoum J. Agric. Res. \& Dev., Vol. 29, No.2, July, 2014 
of vegetation debris (as dry grass and the straw of grain crops), trash from date palms and the dung of herbivorous animals, while relatively small amounts of wood are eaten. Hafez, 1980 referred that Anacanthotermes ochraceus is sometimes regarded as the "straw-cutter" or "grass-cutter" termite. Anacanthotermes favorite food is wheat straw which is obtained from green bricks of which rural houses are made.

The most widely used method for studying the feeding habits of subterranean termites, particularly the polyphagous and wood-feeding species, is the use of baits. These are either presented on soil surface or completely or partially buried. Baits are usually laid out close together in a systematic layout (the so-called graveyard test). Termite food consumption varies according to species and natural food (Nel and Hewitt, 1969). Toilet paper roll baits, litter bags, wooden baits, wooden stake baits and corrugated cardboard or Grass bags are used to measure the relative consumption of different species of termites according to La Fage, et al. 1973; Brian, 1978; Said, 1979; Ali, et al. 1982; Abdel-Wahab, et al. 1983; Salman, et al. 1987; El-Sebay, 1991 and El-Sherif, et al. 2009. Different forms of traps are also used to monitor foraging activity of many groups of termites such as Polyvinylchloride (PVC) collars trap, glass plates, squares or rolls trap of corrugated cardboard (El-Sebay, 1991; Su, et al. 1991; Ahmed, 1997; El-Sherif, et al. 2009 and Abd El-Latif, 2013).

The present study aimed to evaluate the efficacy of different shapes of three traps and five bait materials for monitoring the foraging activity of subterranean harvester termites, Anacanthotermes ochraceus, under field conditions at Ismailia governorate, Egypt.

\section{MATERIALS AND METHODS:}

Asuitable location at El-kasasien district, Ismailia governorate was chosen for the present study. This location is commonly known to be severely infested with A. ochraceus and with no termite control measures practiced there in. Physical and chemical analysis propertied of soil in this location were measured at the Central Laboratory of Soil and Water Analysis, Faculty of Agriculture, Fayoum University.

Experimentation: Two experiments were carried out to evaluate trap shape and bait efficiency.

\section{A- Trap shape efficiency.}

This experiment was carried out for 4 months (April-July 2013) to evaluate the efficacy of three different shapes of termite traps where food consumption and number of captured termites were estimated as follows:

1-The first trap (plate 1A) is made as a plastic rectangular box $20 \mathrm{~cm}$ long, $10 \mathrm{~cm}$ wide and $8 \mathrm{~cm}$ high with a plastic lid. The sides of this box contained 6 small holes; one on each side and 2 on the front and back of the box. Each trap was totally filled with 4 clean corrugated cardboard rolls after being dried at $105^{\circ} \mathrm{C}$ for $24 \mathrm{~h}$ in an electric oven and weighed (100g/trap) then soaked in fresh water

Fayoum J. Agric. Res. \& Dev., Vol. 29, No.2, July, 2014 
until saturation. This trap provides enough nutritive requirements for one month (Abd El-Latif, 2013).

2- The second trap is made of perforated P.V.C. pipe, $15 \mathrm{~cm}$ in diameter and 20 $\mathrm{cm}$ high, filled with a corrugated cardboard roll and covered on both ends with polyethylene sheets kept to the tight pipe with rubber band (plate 1B). Cardboard rolls were dried as usual at $105{ }^{\circ} \mathrm{C}$. for $24 \mathrm{~h}$ in an electric oven and weighed (100g/trap). All termite traps (first ad second shapes) were buried to the depth of 30cm below soil surface. Su, et al. 1991; Ahmed, 1997 and Abd El-Latif, 2003.

3- The third trap is made of corrugated cardboard paper wrapped as rolls that measure 10-12 cm in diameter and $18 \mathrm{~cm}$ in height; all covered with polyethylene sheet, except for the lower most $2 \mathrm{~cm}$. The cover was kept in place with rubber band (Plate 1C). Before use, the cardboard rolls were dried at $105{ }^{\circ} \mathrm{C}$. for $24 \mathrm{~h}$ in an electric oven and weighed $(100 \mathrm{~g} / \mathrm{trap})$ El-Sebay (1991).

The experimental area (10 meters long x 6 meters wide) was chosen carefully and cleaned up from any existing cellulose materials. 5 traps were used for each of the 3 shapes designed. The 15 traps were distributed in 5 rows in 3 columns $2 \mathrm{~m}$ apart. Every trap was left at the same site for 4 months. At the beginning of every month, each trap was lifted up and placed in a plastic bag to be examined in the laboratory where the number of termites existing and food consumption were determined.

\section{Shapes of traps:}

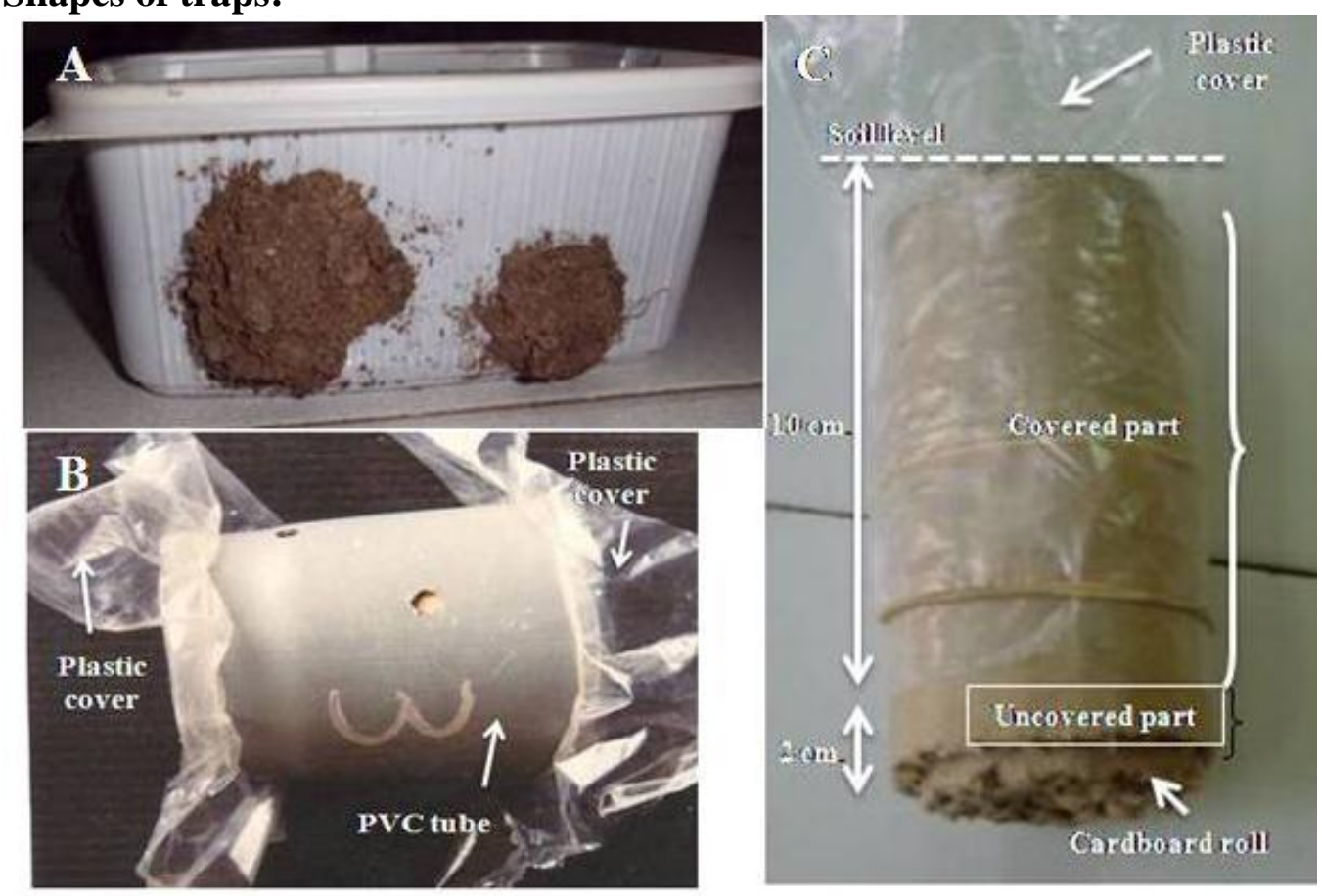

Plate (1): a-Plastic trap, b-P.V.C. trap and c-Corrugated cardboard trap

Fayoum J. Agric. Res. \& Dev., Vol. 29, No.2, July, 2014 


\section{B- Bait efficiency:}

This experiment was carried out for three months (Sept., 2013 -Nov., 2013), in an area (10 m long x $10 \mathrm{~m}$ wide) properly chosen and cleaned up of any existing cellulose materials. Five bait materials; namely corrugated cardboard paper rolls, cellulose, toilet paper rolls, wood particles, and wood stakes of Salix safsaf. The latter is very susceptible to attack by subterranean termite $P$. hybostoma according to Mostafa, et al. 2011.

Before use, the cardboard rolls were dried at $105{ }^{\circ} \mathrm{C}$. for $24 \mathrm{~h}$ in an electric oven and weighed. Only plastic traps were used in 5 replicates for each material. The 25 traps were distributed ( 5 rows in 5 columns) with $2 \mathrm{~m}$ distance between each. At the beginning of every month, the number of termite was obtained as explained above and to estimate foraging activity parameters (food consumption, soil translocation and number of captured termites). Statistical analysis was made for data of number of captured workers, food consumption and soil translocation for used different baiting materials and trap shapes to obtain significant different using SPSS computer program (Duncan, 1955).

Soil translocation by A. ochrachus as in plate (2):
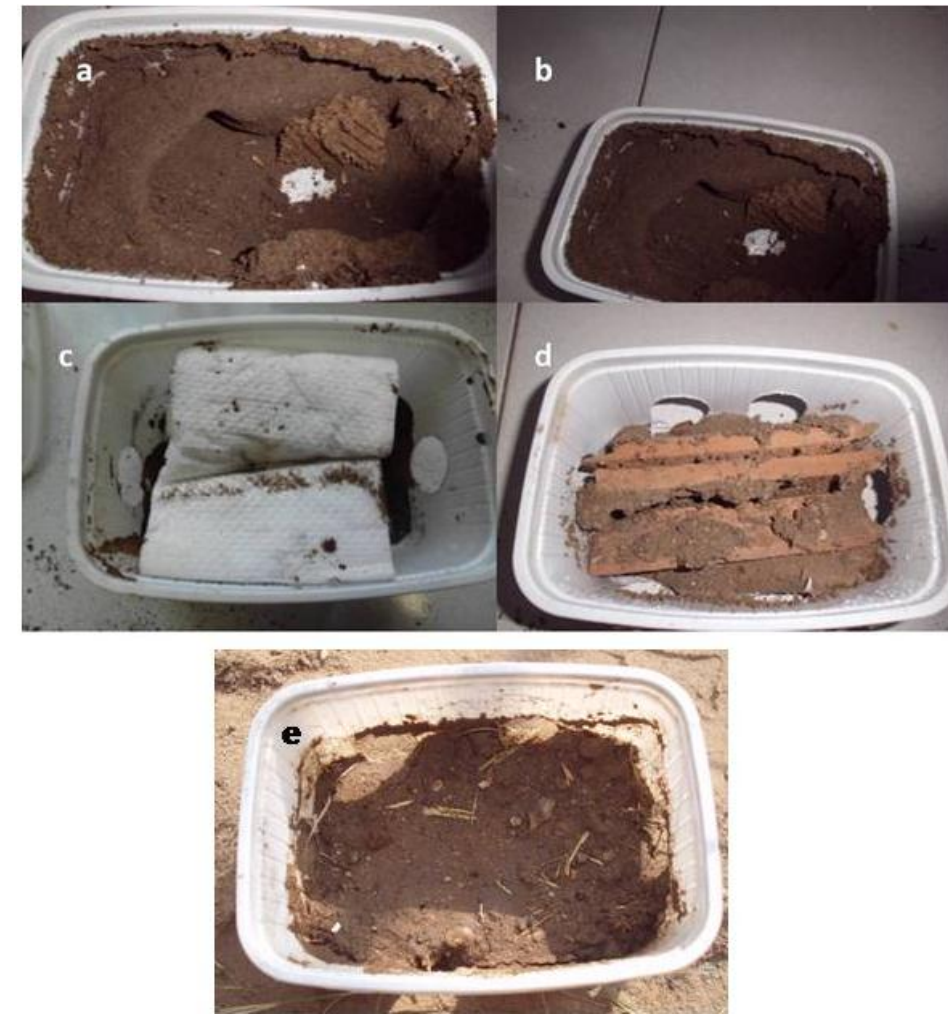

Plate (2):Corrugated cardboard bait material, b-Cellulose bait material, c-Toilet paper bait material $d$-Wooden stakes bait material and e-Wooden particles material

Fayoum J. Agric. Res. \& Dev., Vol. 29, No.2, July, 2014 


\section{RESULTS AND DISCUSSION}

Soil characteristics of study location:

Mechanical analysis: The location soil is Sandy clay loam in texture with $57.1 \%$ sand, $12.1 \%$ silt and $30.8 \%$ clay.

Chemical analysis:

\begin{tabular}{|c|c|c|c|c|c|c|c|c|c|}
\hline \multicolumn{2}{|c|}{ Soluble cations meq./L } & \multicolumn{5}{|c|}{ Soluble anions meq./L } & $\begin{array}{c}\mathbf{E c} \\
\mathbf{m e m} / \mathbf{c m}\end{array}$ & $\mathbf{p H}$ & $\begin{array}{c}\text { OM } \\
\%\end{array}$ \\
\hline $\mathbf{C a}^{++}+\mathrm{Mg}^{++}$ & $\mathrm{Na}^{+}$ & $\mathrm{K}^{+}$ & $\mathrm{CO3}^{-}$ & $\mathrm{HCO3}^{-}$ & $\mathrm{Cl}^{-}$ & $\mathrm{SO}^{-}$ & & & \\
\hline 114 & 159 & 5.96 & 0.0 & 9.9 & 244.4 & 24.6 & 25.37 & 7.53 & 1.25 \\
\hline
\end{tabular}

\section{1-Efficacy of termites traps:}

Data in Table (1) show the monthly means of food consumption and number of captured A. ochraacens termites at Ismailia location for 4 months. Food consumption was estimated as actual dry weight of consumed corrugated paper in each of the three trap shapes used.

Results indicated slight variations in food consumption due to shape of trap but food consumption was almost similar throughout the four months of study. However, the most efficiency was the plastic trap followed by the corrugated card board trap.

The least was the P.V.C. trap. Significant differences were found between the plastic, cardboard, and P.V.C. traps where the mean values of food consumption were $18.29,14.08$, and $6.46 \mathrm{~g} /$ trap with mean values of number of captured termites 11.18, 6.83, and 4.32 individuals/ trap, respectively. Ahmed (1997) estimated the food consumption of A. ochraceus as $36.9 \mathrm{~g} / \mathrm{m}^{2}$ with mean number of foragers 19.96-22.96 individuals/ m. ${ }^{2}$ using P.V.C. traps in Fayoum governorate. Also in the same governorate Abd El latif (2003) estimated the total annual food consumption of A. ochraceus as $58.2 \mathrm{~g} / \mathrm{m}^{2}$ and $57.13 \mathrm{~g} / \mathrm{m}^{2}$ in 1997 and 1998, respectively with mean number of captured workers $/ \mathrm{m}^{2}{ }^{2} 7.4$ and 14.03 , respectively using P.V.C trap. Said (1979) mentioned that the average number of A. ochraceus foragers $/ \mathrm{m}^{2}$ was 0.25 using toilet paper bait traps. In this respect, Abd El latif (2013) estimated the total food consumption of another species, $P$. hybostoma, as 227.9 and $534.5 \mathrm{~g} / \mathrm{trap} / \mathrm{m}^{2}$ in 2010 and 2011, respectively, with mean number of captured workers 4609.6 and 6790.9 individuals/trap/m. ${ }^{2}$, respectively, using plastic trap.

Fayoum J. Agric. Res. \& Dev., Vol. 29, No.2, July, 2014 
Abbas K. M. and Maselleum I. T.

Table (1): A. ochraceus food consumption and number of captured termites /trap for three different shapes of traps at Ismailia governorate (monthly means from April 2013 to July 2013).

\begin{tabular}{|c|c|c|c|c|}
\hline \multicolumn{5}{|c|}{ Trap shape and means/trap } \\
\hline \multicolumn{2}{|c|}{2013} & Plastic & cardboard & P.V.C \\
\hline \multirow{2}{*}{ April } & $\mathrm{C}$ & 17.7 & 14.52 & 6.84 \\
\hline & $\mathrm{N}$ & 10.36 & 5.64 & 4.0 \\
\hline \multirow{2}{*}{ May } & $\mathrm{C}$ & 18.77 & 15.15 & 6.41 \\
\hline & $\mathrm{N}$ & 15.32 & 6.48 & 4.72 \\
\hline \multirow{2}{*}{ June } & $\mathrm{C}$ & 18.44 & 13.17 & 7.61 \\
\hline & $\mathrm{N}$ & 9.52 & 6.2 & 4.24 \\
\hline \multirow{3}{*}{ July } & $\mathrm{C}$ & 18.24 & 13.32 & 4.96 \\
\hline & $\mathrm{N}$ & 9.52 & 9.0 & 4.28 \\
\hline & & \multicolumn{2}{|c|}{ Four month means } & \\
\hline \multirow[b]{2}{*}{ per/trap } & $\mathrm{C}$ & $18.29^{\mathrm{a}}$ & $14.08^{b}$ & $6.46^{\mathrm{c}}$ \\
\hline & $\mathrm{N}$ & $11.18^{\mathrm{a}}$ & $6.83^{\mathrm{b}}$ & $4.32^{c}$ \\
\hline \multirow{2}{*}{ per $/$ m. $^{2}$} & $\mathrm{C}$ & 4.57 & 3.52 & 1.62 \\
\hline & $\mathrm{N}$ & 2.79 & 1.71 & 1.08 \\
\hline
\end{tabular}

C: consumption

$\mathrm{N}$ : Number of captured termites

\section{2-Efficacy termites baits:}

\section{A-Food consumption:}

Data in Table (2) show that the highest food consumption occurred with corrugated cardboard while the lowest food consumption was in wooden stakes. Significant differences were evident between cardboard and cellulose and the other materials; namely toilet paper, wooden particles and wooden stakes. However, no significant differences were detected between mean food consumption between corrugated cardboard and cellulose or between toilet paper and wooden particles.

Table (2): Monthly means of food consumption by A. ochraceus using five bait materials at Ismailia governorate throughout Sept. 2013 -Nov. 2013.

\begin{tabular}{|c|c|c|c|c|c|}
\hline \multirow[b]{2}{*}{$\begin{array}{l}\text { Observation } \\
\text { Months }\end{array}$} & \multicolumn{5}{|c|}{ Bait material \& food consumption g/trap } \\
\hline & cardboard & Cellulose & Toilet paper & $\begin{array}{l}\text { Wooden } \\
\text { particles }\end{array}$ & $\begin{array}{c}\text { Wooden } \\
\text { stakes }\end{array}$ \\
\hline September & 91.60 & 91.36 & 51.82 & 52.0 & 28.1 \\
\hline October & 88.80 & 86.92 & 52.38 & 45.47 & 25.08 \\
\hline November & 93.60 & 87.94 & 60.58 & 56.0 & 16.5 \\
\hline Mean g/trap & $91.33^{\mathrm{a}}$ & $88.73^{\mathrm{a}}$ & $54.93^{\mathrm{b}}$ & $51.16^{\mathrm{b}}$ & $23.23^{\mathrm{c}}$ \\
\hline Mean $/ \mathrm{m}^{2}$ & 22.83 & 22.18 & 13.73 & 12.79 & 5.81 \\
\hline
\end{tabular}

Ahmed (1997) estimated the food consumption of A. ochraceus as $36.9 \mathrm{~g} / \mathrm{m}^{2}$ using corrugated cardboard and Abd El latif (2003) estimated the total annual food consumption as 57.13-58.2 g/m. ${ }^{2}$ Mostafa, et al. 2011 reported the mean weight

Fayoum J. Agric. Res. \& Dev., Vol. 29, No.2, July, 2014 
COMPARATIVE EFFICIENCY OF DIFFERENT SHAPES AND.

loss of Salix safsaf H.W. blocks as $6.98 \mathrm{~g}$ with wood consumption $97.62 \%$ after 6.60 months of field exposure.

\section{B-Soil translocation:}

Data in Table (3) indicated that the largest quantity of translocated soil by termites occurred in corrugated cardboard and cellulose materials where the rate of soil translocation was almost similar $(121 \mathrm{~g} /$ trap) while the lowest quantity was with wooden stakes. Statistical analysis revealed no significant differences between mean values of soil translocation in corrugated cardboard and cellulose bait materials and also between toilet paper and wooden particles or between toilet paper and wooden stakes. Meanwhile, significant differences were found between cardboard or cellulose and each of toilet paper, wooden particles and wooden stakes. According to Collins and Nutting (1973) and Said (1979) the workers of $A$. ochraceus exchange a load of soil for a bit of food material. The changes in soil translocation were almost similar to those previously described for food consumption. This phenomenon seems quite understood as the increase or decrease of food consumption is correlated to subsequent increases or decreases of soil translocation whereas, the relationship was positive and highly significant between food consumption and soil translocation Abd El latif (2013).

Ahmed (1997) stated that in Fayoum governorate of Egypt the soil translocated by A.ochraceus amounts to $131-170 \mathrm{~g} . / \mathrm{m}^{2}$ using corrugated cardboard bait. Also Abd El latif (2003) estimated the total dry weight of translocated soil as $426.52 \mathrm{~g} / \mathrm{m}^{2}$ in 1997 and $484.66 \mathrm{~g} / \mathrm{m}^{2}$ in 1998. In this respect, Abd El latif (2013) estimated total amounts of soil translocation by $P$. hypostoma throughout 2010 and 2011 and were 464.22 and $1714.95 \mathrm{~g} / \mathrm{m}^{2}$, respectively using corrugated cardboard bait.

Table (3): Monthly means of Soil translocation by $A$. ochraceus using five bait materials at Ismailia governorate throughout Sept. 2013Nov.2013.

\begin{tabular}{|c|c|c|c|c|c|}
\hline \multirow{2}{*}{$\begin{array}{c}\text { Observation } \\
\text { Months }\end{array}$} & \multicolumn{5}{|c|}{ Bait material \& soil translocation in g/ trap } \\
\cline { 2 - 6 } & Cardboard & Cellulose & Toilet paper & $\begin{array}{c}\text { Wooden } \\
\text { particles }\end{array}$ & $\begin{array}{c}\text { Wooden } \\
\text { stakes }\end{array}$ \\
\hline September & 116.60 & 111.02 & 49.08 & 42.77 & 51.02 \\
\hline October & 126.80 & 119.02 & 45.78 & 61.1 & 37.34 \\
\hline November & 121.60 & 133.16 & 40.46 & 66.33 & 33.02 \\
\hline Mean/trap & $121.67^{\mathrm{a}}$ & $121.07^{\mathrm{a}}$ & $45.11^{\mathrm{cb}}$ & $56.73^{\mathrm{b}}$ & $40.46^{\mathrm{c}}$ \\
\hline Mean/m. & 30.42 & 30.27 & 11.28 & 14.18 & 10.12 \\
\hline
\end{tabular}

C-Number of captured termites:

Data in Table (4) indicated that the largest number of captured termites were in corrugated cardboard (66.67 individuals/trap) while the lowest numbers was in wooden stakes (8.71 individuals/trap). The same trend as previously mentioned in soil translocation, no significant differences between mean values of

Fayoum J. Agric. Res. \& Dev., Vol. 29, No.2, July, 2014 
Abbas K. M. and Maselleum I. T.

number of captured termites in corrugated cardboard and cellulose bait materials and also between mean values of number of captured termites in toilet paper and wooden particles or between toilet paper and wooden stakes. Meanwhile, significant differences were found between cardboard or cellulose and each of toilet paper, wooden particles and wooden stakes.

Table (4): Monthly means of $A$. ochraceus captured by using five bait materials at Ismailia governorate throughout Sept. 2013 - Nov. 2013.

\begin{tabular}{|c|c|c|c|c|c|}
\hline \multirow{2}{*}{$\begin{array}{c}\text { Observation } \\
\text { Months }\end{array}$} & \multicolumn{4}{|c|}{ Bait material \& number of captured termites/ trap } \\
\cline { 2 - 6 } & Cardboard & Cellulose & Toilet paper & $\begin{array}{c}\text { Wooden } \\
\text { particles }\end{array}$ & $\begin{array}{c}\text { Wooden } \\
\text { stakes }\end{array}$ \\
\hline September & 61.2 & 60.6 & 20.0 & 27.7 & 10.25 \\
\hline October & 63.2 & 70.6 & 20.6 & 29.0 & 8.6 \\
\hline November & 75.6 & 64.6 & 15.8 & 37.0 & 7.6 \\
\hline Mean/trap & $66.67^{\mathrm{a}}$ & $65.27^{\mathrm{a}}$ & $18.8^{\mathrm{cb}}$ & $31.22^{\mathrm{b}}$ & $8.71^{\mathrm{c}}$ \\
\hline Mean/m. & 16.87 & 16.32 & 4.7 & 7.81 & 2.18 \\
\hline
\end{tabular}

REFERENCES:

Abd El Latif, A. N. (2003): Ecological and control studies on certain subterranean termites species Ph. D. Thesis, Fac. Agric. Cairo Univ. 260 p.

Abd El Latif, A. N. (2013): Foraging activity parameters of the sand subterranean termite, Psammotermes hybostoma Desneux (Isoptera: Rhinotermitidae) and its associated fungus Metarhizium anisopliae under the field conditions at El-Fayoum governorate, Egypt. Egyptian journal of plant protection 8 (2):8-20.

Abdel-Wahab, M. A.; Rizk, M. R.; Hussein, M. H.; Abd El-Raof, T. K. and ElTaib, M. S. (1983): Surface activity of sand termite Psammotermeshybostoma (Desneux) in Asswan, Assuit J. Agric. Sci., 14 (3): 99-108.

Ahmed, H. M. (1997): Ecological studies and control of harvester subterranean termite Anacanthotermesochraceus (Burm.) at El Fayoum Governorate. M.Sc. Thesis, Fac. Agric., CairoUniv.at El Fayoum branch $77 \mathrm{p}$.

Ali, A. M.; Abou-Ghadir, M. F. and Abdel Hafez, N. A. (1982): Surface activity of termite in the NewValley. Assuit J. Agric. Sci., 13 (3): 73-78.

Ali, A. M. (1980): Control of termites in Egypt-present and future. Sociobiology, 5 (2): 211-212.

Brian, M. V. (1978): Production ecology of ants and termites. Cambridge Univ. Press.London.409 p.

Duncan,D. B. (1955): Multiple range and multiple F. tests. Biom., 11:1-42.

El-Sebay, Y. (1991): A modified El-Sebay trap for subterranean termites. Fourth Arab.Congress of Plant Protection.Cairo, Egypt, Dec. 1991 pp. 245247.

El-Sherif,S.I., El-Sebay, Y.M. and Abd El-latif, N.A. (2009): Foraging activity of Fayoum J. Agric. Res. \& Dev., Vol. 29, No.2, July, 2014 
COMPARATIVE EFFICIENCY OF DIFFERENT SHAPES AND.

the subterranean termite,Anacanthotermes ochraceus ( Burmeister) at El-Fayoum Governorate , Egypt. Fayoum J. Agric. Res.7 Dev., 23 (2):55-64.

Hafez, M. (1980): Highlights of the termite problem in Egypt. Sociobiology, 5 (2): 147-154.

Harris, W. V. (1961): Termites their recognition and control. Longmans, London, $187 \mathrm{p}$.

Harris, W. V. (1970): Termites of the Palaearctic Region, pp. 295-313. "In Biology of termites," Krishna, K. and Weesner, F. M. (eds.) Vol. II Academic press, New York.

Kaschef, A. H. and El-Sherif, L. S. (1971): Distribution of four termite species in the A. R. Egypt. InsectesSociaux, 18 (4): 227-232.

Kassab, A.; Hassan, M. I.; Charawi, A. M. and Shahwan, A. M. (1960): The termite problem in Egypt with special reference to control. Min. Agric. Publ. Cairo, $91 \mathrm{P}$.

La Fage, J. P.; Nutting W. L. and Haverty, M. I. (1973): Desert subterranean termite: A method for studying foraging behavior. Environ. Entomol., 2: 954-956.

Mostafa F. F.; Abdel El-Latif A. Nadia and Shahin A. Mustafa (2011): Susceptibility of certain Egyptian and Iraqi wood to infestation by Psammotermes hybostoma Desneux, in Fayoum governorate, Egypt. Bull. Ent. Soc.Egypt.88:179-190.

Nel, J. J. C. and Hewitt, P. H. (1969): A study the food eaten by a field population of the harvester termite, Hodotermes mossambicus (Hagen) and its relation to population density. Entomol. Society of Southern Africa, 32: 123-131.

Salman, A. G. A; Morsy, M. A. and El. Sayed, A. A. (1987): Foraging activity of the sand termite, Psammotermeshybostoma (Desn.) in the New Valley, Egypt. Assuit J. Agric. Sci., 18(4): 51-57.

Said, W. A. (1979): Ecological and toxicological studies on Family Hodotermitidae. M. Sc. Thesis, Fac. Agr. Ain Shams Univ.

Su, N. Y.; Ban, P. M. and Scheffrahn, R. H. (1991): Suppression of foraging populations of the Formosan subterranean termites (Isoptera: Rhinotermitidae) by field applications of a slow-acting toxicant bait. J. Econ. Entomol., 84 (5): 1925-1531.

Fayoum J. Agric. Res. \& Dev., Vol. 29, No.2, July, 2014 
Anacanthotermes ochraceus مقارنة كفاءة الاشكال والمواد المختلفة للمصائد النمل التحت ارضي

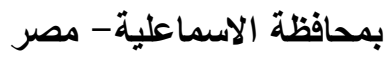

\section{محمد كمال عباس ، وتامر (براهيم مسلم}

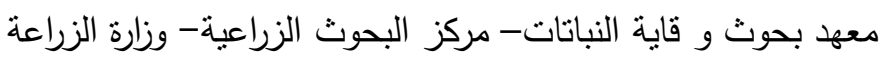

اجريت هذه الدراسة فى محطة القصاصين بمحافظة الاسماعلية لمدة أربعة شهور من إبريل حتي

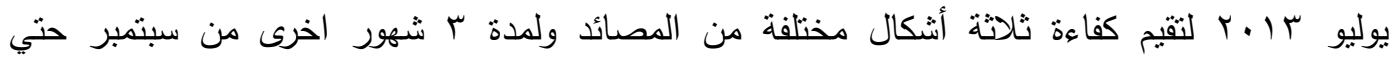
نوفمبر با • ץ لتقيم كفاءة خمسة انواع من الطعوم للنمل الحاصد A. ochraceus. اوضحت النتائج ان الاستهلاك الغذائي للنمل الحاصد اختلف بشكل المصبدة بالرغم من تثابة الاستهلاك الغذائي خلال اربعة اشهر الدراسة حيث كانت اكفأ المصائد هى المصبدة البلاستيكية تليها المصيدة الكروتتية ثم مصيدة

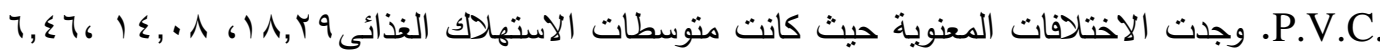

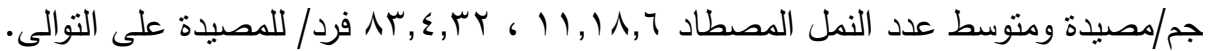

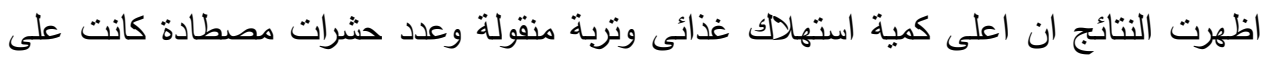
الترتيب مع مادة الكرتون المجعد، والسليلوز، ورق التواليت، وحبيبات الخشب، واخيرا عيدان الخشب. كان

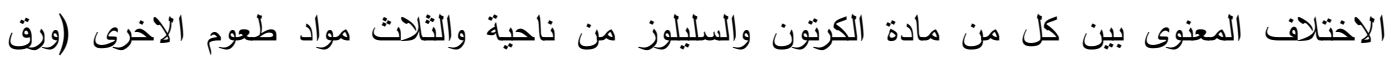
التواليت، وحبيبات الخشب، وعيدان الخشب) من ناحية اخرى. 